\title{
Impact of estrogen receptor $\alpha$ gene and oxytocin receptor gene polymorphisms on female sexuality
}

\section{Anastasia K Armeni', Konstantinos Assimakopoulos', Dimitra Marioli', Vassiliki Koika', Euthychia Michaelidou ${ }^{3}$, Niki Mourtzi ${ }^{3}$, Gregoris Iconomou ${ }^{2}$ and Neoklis A Georgopoulos ${ }^{1}$}

${ }^{1}$ Division of Reproductive Endocrinology, Department of Obstetrics and Gynaecology, University of Patras Medical School, Patras, Greece

${ }^{2}$ Department of Psychiatry, University of Patras Medical School, Patras, Greece

${ }^{3}$ Department of Biology, University of Patras, Patras, Greece

\begin{abstract}
Over the past decades, research attention has increasingly been paid to the neurobiological component of sexual behavior. The aim of the present study was to investigate the correlation of estrogen receptor $\alpha(E R A)$ gene polymorphism ( $r$ 22234693-Pvull) ( $T \rightarrow C$ substitution) and oxytocin receptor gene polymorphism ( $r 553576$ ) ( $\rightarrow$ A substitution) with sexuality parameters of young, healthy women. One hundred thirty-three Greek heterosexual women, students in higher education institutions, 20-25 years of age, sexually active, with normal menstrual cycles (28-35 days), were recruited in the study. Exclusion criteria were chronic and/or major psychiatric diseases, use of oral contraceptive pills (OCs), polycystic ovary syndrome (PCOS), thyroid diseases as well as drugs that are implicated in hypothalamus-pituitarygonadal axis. T allele (wildtype) of rs2234693 (Pvull) polymorphism of ERA gene was correlated with increased levels of arousal and lubrication, whereas A allele (polymorphic) of rs53576 (OXTR) polymorphism was correlated with increased arousal levels. The simultaneous presence of both T allele of rs2234693 (Pvull) and A allele of rs53576 (OXTR) polymorphisms ( $\mathrm{T}+\mathrm{A}$ group) was correlated with increased arousal, orgasm levels as well as female sexual function index full score. To our knowledge, this is the first study to investigate the interaction between ERA and OXTR with regard to sexual function in women. Female sexuality is a complex behavioral trait that encompasses both biological and psychological components. It seems that variability in female sexual response stems from genetic variability that characterizes endocrine, neurotransmitter and central nervous system influences.
\end{abstract}

Correspondence should be addressed to N A Georgopoulos Email neoklisg@hol.gr

\section{Introduction}

Over the past decades, research attention has been increasingly paid to the examination of the neurobiological component of sexual function.

Female sexual desire and arousal have been shown to have a heritable component of moderate size. Data have shown that additive and non-additive genetic effects explained $21-35 \%$ of the variation in

\section{Key Words}

- estrogen receptor $\alpha$ gene polymorphism

- oxytocin receptor gene polymorphism

- female sexuality desire, $24-26 \%$ in subjective arousal and $16-25 \%$ in lubrication $(1,2)$.

Central regulatory role of estrogens in female sexuality is unequivocal. Estrogens exert a direct effect on hypothalamic neurons at hyperchiasmatic level, especially on paraventricular nucleus (PVN), ventromedial nucleus (VMN), cortical areas (occipital-temporal

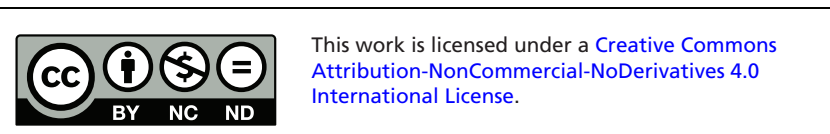


cortex, ventral procinetic cortex and medial prefrontal cortex), hippocampus, central nucleus of amygdala and pedunculopontine nucleus (PPN) $(3,4,5,6,7)$. Furthermore, peripheral actions of estrogens also promote female sexuality, including vaginal trophic effects as well as increase in skin sensitivity (8).

Estrogens binding to estrogen receptors (ERA or ERB) activate estrogen-responsive genes and stimulate ER-positive cell lines. Although single-nucleotide polymorphisms (SNPs) of ERB gene (rs1271572, rs4986938 and rs928554) have been associated with sexual desire and lubrication (9), the involvement of ERA gene polymorphisms in the variation of female sexual functioning has not been evidenced $(9,10)$. Rs2234693 (PvuII) polymorphism is a common SNP (42\% in Caucasians), located in intron 1 of ERA gene in which thymine is substituted by cytosine $(\mathrm{T} \rightarrow \mathrm{C})$. The presence of the dominant $\mathrm{T}$ allele of PvuII polymorphism can enhance ERA activity (11). Although increased reproductive efficiency has been associated with wildtype allele of PvuII polymorphic site (12), the implication of rs2234693 has not been associated with sexual function.

Oxytocin is a peptide associated with behavioral and psychological traits such as enhancement of pair bonding and affiliation; establishment of social bonds; decrease of social anxiety and increase of empathy, emotion recognition and interpersonal trust (13). Oxytocin is detected in peripheral tissues such as uterus, placenta, corpus luteum, playing a role in lactation and in contraction of the smooth muscle of the uterus during parturition. Furthermore, oxytocin is detected in the central nervous system (CNS), mainly in hypothalamic areas (paraventricular PVN and supraoptic SON nuclei, bed nucleus of the stria terminalis-BNST and in medial prooptic area-MPOA) and several nuclei of the amygdala.

Oxytocin is implicated both in social behavioral network $(14,15)$ and in sexual response. Increased oxytocin levels have been reported during sexual arousal, reaching peak levels during orgasm, whereas increased oxytocin levels have been confirmed immediately after orgasm. Furthermore, oxytocin levels have positively been correlated with intensity of contractions of the pelvic musculature during orgasm $(16,17,18,19)$.

Oxytocin receptor (OXTR) is a 389 amino acid polypeptide with 7 transmembrane domains that belong to the class I G protein-coupled receptor (GPCR) family (20). Rs53576 is an SNP substitution of guanine by adenine $(\mathrm{G} \rightarrow \mathrm{A})$, which has thoroughly been studied and linked to socially related personality traits and behaviors (21).
Sexual response is attributed to coordinated genital reflexes that are influenced by estrogens and oxytocin. The lumbosacral spinal cord is the final source of output to the genital musculature, whose activity is modulated by a number of descending brain systems that regulate somatic genital reflexes. Certain brain areas of the thalamus seem to play a stimulatory role in the coordination of rhythmic contractions of the genital musculature via these lumbosacral targets. These thalamic areas are the spinothalamic neural cells in the lumbar spinal cord (LSt), in conjunction with the subparafascicular parvocellular nucleus (SPFpc) of the thalamus. On the other hand, the lumbosacral targets are under tonic inhibition provided by the nucleus paragigantocellularis (nPGi), which receives projections from hypothalamic nuclei (MPOA and PVN) and the periaqueductal gray matter (PAG). Estrogen receptors have been detected in MPOA, PVN and PAG nuclei, illustrating the strong estrogenic input of these areas. Ascending genitosensory information has been shown to influence these lumbosacral targets either directly or indirectly via brain regions associated with the regulation of sexual behavior, including the oxytocin receptors-containing neurons in the PVN (22).

Although female sexuality has been associated with $E R B$ gene polymorphisms, ERA gene polymorphisms have not been related to sexuality parameters $(9,10)$. In fact, the estrogen effect on sexuality is the result of ERA and ERB interaction. Consequently, the role of ERA in female sexuality is crucial compared to that of ERB, given that $E R A$ knockout mice did not display sexual behavior, whereas ERB knockout mice exhibited lordosis behavior equal to wildtype ones (23).

The importance of female sexuality in investigating genetic components lies in the organizational effects of estradiol and oxytocin on human CNS. Behaviors that have traditionally been associated with oxytocin's acute neuromodulatory effects, such as affiliative and sexual behaviors have been shown to establish a long-lasting pattern depending on the exposure pattern of oxytocin in early postnatal development and during puberty (14). Furthermore, it seems that estradiol has organizational effects on certain behaviors. The old concept that female differentiation develops in the absence of any hormonal influence has been re-examined, as it has been shown that estradiol is required during development for the expression of sociosexual behaviors in adult female mice (24).

We could hypothesize that ERA gene polymorphism rs2234693 and OXTR gene polymorphism rs53576 could be implicated on human sexuality parameters. 
Our hypothesis was based on previous findings relating rs2234693 to increased affinity for estrogens as well as to higher circulating estrogen levels (25). In addition, research into humans has underlined the strong involvement of rs53576 on social functions such as parenting, empathy and using of social relationships to manage stress (26). Indeed, a regulatory interplay between oxytocinergic system and gonadal steroids is well established. Estrogens have been shown to increase oxytocin receptor binding (27), whereas oxytocin has been shown to increase expression of ER $\alpha$ (28). Therefore, the interaction of these two genetic polymorphisms could have an additive effect on female sexuality.

The aim of the present study was to investigate the correlation of estrogen receptor $\alpha$ (ER $\alpha)$ gene polymorphism (rs2234693-PvuII) and oxytocin receptor gene polymorphism (rs53576) with sexuality parameters of young healthy women. This is the first study to investigate the interaction between ERA and OXTR in relation to sexual function in women.

\section{Subjects and methods}

Initially, one hundred ninety-four Greek heterosexual women aged 20-25 years old, sexually active, voluntarily participated in the study. One hundred women were students of childbirth assistance of Technological Educational Institute of Athens, whereas ninety-four women were medical students of University of Patras Medical School. Women were recruited after their attendance of two workshops on female sexuality organized by the Division of Reproductive Endocrinology, Department of Obstetrics and Gynaecology of the Medical School, University of Patras. Exclusion criteria were chronic diseases, major psychiatric disorders, use of oral contraceptive pills (OCs), polycystic ovary syndrome (PCOS), thyroid diseases as well as drugs that are implicated in hypothalamus-pituitary-gonadal axis. Women on OCs or on drugs that are implicated in hypothalamus-pituitary-gonadal axis were excluded due to their inhibited ovarian hormone secretion. Psychiatric diseases are a possible co-variant of sexuality parameters, and thus, they should be taken into account in a model constructed by multiple regression. In our study, only genetic components were examined and the study population should be homogeneous, clearly having or not having psychiatric morbidity. Consequently, women with major psychiatric disorders were excluded from the study. Due to disclosed hyperandrogenism and/or anovulation in 61 women, only 133 women with normal ovulatory menstrual cycles (28-35 days) were finally enrolled in the study. All eligible participants were students in higher education institutions and gave written informed consent before study entry. The conduct of the study was approved by the Institutional Review Board of Patras Medical School, functioning according to the 3rd edition of the Guidelines on the Practice of Ethical Committees in Medical Research issued by the Royal College of Physicians of London.

Height and weight were measured, and body mass index (BMI) $\left(\mathrm{kg} / \mathrm{m}^{2}\right)$ was calculated. Hormonal determinations of follicular (1st-4th day of menstrual cycle) and luteal phase (18th-21st day) were conducted. Luteinizing hormone (LH), follicle-stimulating hormone (FSH), estradiol, testosterone and sex hormone-binding globulin (SHBG) were measured, whereas Free Androgen Index (FAI) was calculated on follicular phase. Progesterone levels were measured on luteal phase of menstrual cycle. $\mathrm{LH}, \mathrm{FSH}$ and testosterone were determined based on Chemiluminescence (Elecsys 2010, Roche Diagnostics), whereas SHBG and progesterone were measured by RIA (BioSource, B-1400 Nivelles-Belgium).

\section{Questionnaires}

Sexual function was measured by the Greek version of the Female Sexual Function Index (FSFI) (29), a 19-item multiple choice questionnaire, which we have used in previous research $(30,31,32)$. The FSFI is an internationally accepted and reliable instrument for rating female sexual function for research or clinical use (33). It measures six domains, including sexual desire, arousal (subjective), lubrication, orgasm, satisfaction and pain over the past 4 weeks. The six domain scores are summed to produce a full-scale score. For all FSFI domains, higher values indicate a better level of function (29). Moreover, age of adrenarche, menarche, age of first intercourse and also number of sexual partners were included in the questionnaires.

\section{Study of genetic polymorphisms}

DNA extraction was conducted by leukocytes of peripheral blood using the method of phenol. Study of rs2234693 $(\mathrm{T} \rightarrow \mathrm{C})$ polymorphism of estrogen receptor $\alpha(E R \alpha)$ gene was realized by amplification of genetic sequence using the method of polymerase chain reaction (PCR). The primers were: (ER-F): 5'-CTG CCA CCC TAT 
CTG TAT CTT TTC CTA TTC TCC-3' and (ER-R): 5'-TCT TTC TCT GCC ACC CTG CGT CGA CCA TCT GA-3'. Reactions were carried out using the following parameters (35 cycles): $94^{\circ} \mathrm{C}$ for $4 \mathrm{~min}, 94^{\circ} \mathrm{C}$ for $45 \mathrm{~s}, 58^{\circ} \mathrm{C}$ for $45 \mathrm{~s}$ and $72^{\circ} \mathrm{C}$ for $1 \mathrm{~min}$. Amplification was confirmed by gel agarose electrophoresis. Detection of rs2234693 polymorphism was conducted using restriction enzyme PvulI following gel agarose electrophoresis.

Study of rs53576(G $\rightarrow$ A) polymorphism of oxytocin receptor gene $(O X T R)$ was conducted using PCR method. The primers were F: 5'-GCC CAC CAT GCT CTC CAC ATC-3' ' $^{\prime}$ R: 5'-GCT GGA CTC AGG AGG AAT AGG GAC-3'. Amplification was confirmed by gel agarose electrophoresis. Detection of rs53576 polymorphism was conducted using restriction enzyme BamHI.

\section{Statistical analysis}

Statistical analysis was conducted using SPSS 15.0 for Windows (IBM SPSS Statistics, IBM software). Test of normality for distribution of variables was done by Kolmogorov-Smirnov test. All parameters are presented as mean value ( \pm S.D. value) (mean \pm S.D.), regardless of their distribution. Study of Hardy-Weinberg equilibrium between observed and expected genotype frequencies was done using $\chi^{2}$ goodness-of-fit test. The sample was in Hardy-Weinberg equilibrium for a
Table 1 Anthropometric and hormonal characteristics $(N=133)$.

\section{Variable}

Mean (s.D.)

Age

Height (m)

Weight $(\mathrm{kg})$

Body mass index (BMI)

Estradiol $\left(\mathrm{E}_{2}\right)(\mathrm{pg} / \mathrm{mL})$

Testosterone $(\mathrm{ng} / \mathrm{mL})$

FAI (\%)

$\mathrm{LH}(\mathrm{IU} / \mathrm{mL})$

FSH (IU/mL)

SHBG (nmol/L)

Progesterone (ng/mL)

$21.62(1.92)$

$1.64(0.05)$

$59.88(12.14)$

$22.09(4.00)$

$43.64(15.20)$

$0.31(0.08)$

1.98 (1.40)

$5.94(2.20)$

6.53 (1.54)

$69.54(29.78)$

9.76 (7.39)

polymorphism when $P>0.05$. The comparison of mean values among three genotype groups was analyzed with one-way ANOVA for normally distributed variables and the Kruskal-Wallis one-way ANOVA for non-normally distributed variables. The comparison of mean values between two genotype groups was done by independent samples $t$-test for normally distributed variables and the Mann-Whitney test for non-normally distributed variables. Two-tailed significance level was set at 5\%. The effect sizes of normal distributions were calculated, based on the equation $r=V\left(t^{2} /\left(t^{2}+d f\right)\right)$, where $t$-statistic was preferred for both $t$-tests and contrasts of ANOVA, comparing only two things per test, and $d f$ was degrees of freedom. Similarly, z-score was used for calculating

Table 2 Hormonal characteristics and sexual parameters among rs2234693 (Pvull) genotype groups (homozygous for T wild-type allele, homozygous for C polymorphic allele and heterozygous) and rs53576 (OXTR) genotype groups (homozygous for G wild-type allele and carriers of A polymorphic allele) (bold indicates significance level: $P<0.05$ ).

\begin{tabular}{|c|c|c|c|c|c|c|c|}
\hline & \multicolumn{4}{|c|}{ ERA } & \multicolumn{3}{|c|}{ OXTR } \\
\hline & $\mathrm{TT}(N=38)$ & $\mathrm{TC}(N=64)$ & $C C(N=31)$ & $P$ value & GG $(N=64)$ & GA/AA $(N=69)$ & $P$ value \\
\hline Age & $21.42(2.04)$ & $21.62(1.96)$ & $21.87(1.72)$ & 0.299 & $21.68(2.08)$ & 21.56 (1.78) & 0.987 \\
\hline $\mathrm{FSH}(\mathrm{IU} / \mathrm{mL})$ & $6.57(1.32)$ & $6.48(1.77)$ & $6.57(1.32)$ & 0.952 & $6.64(1.58)$ & $6.42(1.51)$ & 0.402 \\
\hline LH (IU/mL) & $5.98(2.46)$ & $5.89(2.18)$ & $5.98(1.97)$ & 0.84 & $5.91(2.14)$ & $5.97(2.28)$ & 0.861 \\
\hline $\mathrm{E} 2(\mathrm{pg} / \mathrm{mL})$ & $43.46(14.30)$ & $43.50(14.64)$ & $44.14(17.71)$ & 0.999 & $44.46(16.52)$ & 42.87 (13.94) & 0.804 \\
\hline Progesterone (ng/mL) & $9.29(8.35)$ & $10.03(6.75)$ & $9.79(7.62)$ & 0.496 & $9.88(7.79)$ & $9.66(7.05)$ & 0.941 \\
\hline Testosterone (ng/dL) & $0.32(0.08)$ & $0.31(0.08)$ & $0.30(0.09)$ & 0.61 & $0.32(0.08)$ & $0.30(0.09)$ & 0.183 \\
\hline SHBG (nmol/L) & $64.51(30.91)$ & 70.72 (31.49) & $73.27(24.32)$ & 0.237 & $68.07(29.9)$ & $70.90(29.82)$ & 0.415 \\
\hline FAI & $2.24(1.54)$ & $1.98(1.49)$ & $1.68(0.95)$ & 0.126 & 2.07 (1.44) & $1.90(1.37)$ & 0.208 \\
\hline Desire & $4.46(0.86)$ & $4.19(0.92)$ & $4.10(1.07)$ & 0.252 & $4.11(0.96)$ & $4.37(0.92)$ & 0.155 \\
\hline Arousal & $5.48(0.48)$ & $4.96(1.31)$ & $4.61(1.38)$ & 0.004 & $4.95(1.13)$ & $5.10(1.24)$ & 0.04 \\
\hline Lubrication & $5.58(0.66)$ & $5.22(1.33)$ & $5.03(1.25)$ & 0.046 & $5.27(1.19)$ & $5.29(1.15)$ & 0.993 \\
\hline Orgasm & $5.15(0.96)$ & $4.66(1.53)$ & $4.55(1.50)$ & 0.211 & $4.66(1.40)$ & $4.88(1.39)$ & 0.152 \\
\hline Satisfaction & $5.44(0.90)$ & $5.20(1.20)$ & $4.96(1.06)$ & 0.058 & $5.25(1.14)$ & $5.17(1.06)$ & 0.39 \\
\hline Pain & $4.88(1.46)$ & $5.02(1.61)$ & $4.82(1.53)$ & 0.521 & $5.05(1.42)$ & $4.83(1.65)$ & 0.543 \\
\hline FSFI_full & $31.02(3.21)$ & $29.27(6.64)$ & $28.10(6.26)$ & 0.075 & $29.32(5.71)$ & $29.67(5.97)$ & 0.265 \\
\hline Menarche & $12.36(1.14)$ & $12.30(1.35)$ & $12.45(1.31)$ & 0.482 & $12.46(1.43)$ & $12.26(1.12)$ & 0.632 \\
\hline Adrenarche & $10.36(1.23)$ & $10.34(1.35)$ & $10.25(1.54)$ & 0.769 & $10.56(1.51)$ & $10.11(1.18)$ & 0.172 \\
\hline Age of first intercourse & $17.84(1.91)$ & $17.89(1.99)$ & $17.70(1.73)$ & 0.915 & $18.06(1.91)$ & $17.62(1.87)$ & 0.095 \\
\hline Number of sex partners & $3.84(4.73)$ & $3.67(3.58)$ & $2.93(2.36)$ & 0.785 & $3.46(4.26)$ & $3.62(3.16)$ & 0.442 \\
\hline
\end{tabular}

http://www.endocrineconnections.org DOI: 10.1530/EC-16-0090
() 2017 The authors Published by Bioscientifica Ltd
This work is licensed under a Creative Commons Attribution-NonCommercial-NoDerivatives 4.0 International License. 
effect sizes of non-normal distributions, based on the equation $r=z / V N$, where $N$ represented the total number of observations. The statistics evaluating the associations between the individual SNPs and the outcome are of primary interest, and the type I error inflation due to multiple comparisons is typically addressed by procedures that control the family-wise error rate (such as the Bonferroni correction) or by determining the false discovery rates and $q$ values. Consequently, the threshold for overall significance will be lower, thereby increasing power. It has been argued that correction for multiple testing in hypothesisdriven candidate gene association studies are too strict (34), and it was not conducted in the present study.

\section{Results}

Anthropometric and hormonal values of the sample are presented in Table 1. Mean values of testosterone and estradiol were within normal range, whereas women were normovulatory. Allele frequencies for each one of the polymorphisms were the following: concerning rs2234693 (ERA-PvuII), frequency of T allele (wildtype) was $52.6 \%$, whereas frequency of $\mathrm{C}$ allele was $47.4 \%$. Concerning rs53576 (OXTR), frequency of $\mathrm{G}$ allele (wildtype) was $71.8 \%$, whereas frequency of A allele was $28.2 \%$ (data not shown). It was shown that rs2234693
(ERA-PvuII) and rs53576 (OXTR) polymorphisms were in Hardy-Weinberg equilibrium.

It was also shown that $\mathrm{T}$ allele (wildtype) of rs2234693 (PvuII) polymorphism was correlated with increased arousal levels $(P=0.004, r=0.39$, medium effect $)$ and increased lubrication levels $(P=0.046, r=0.31$, medium effect) (Table 2).

Moreover, it was shown that A allele (polymorphic) of rs53576 (OXTR) polymorphism was correlated with increased arousal levels $(P=0.040, r=0.17$, small effect) (Table 2).

The simultaneous presence of both $\mathrm{T}$ allele of rs2234693 (PvuII) and A allele of rs53576 (OXTR) polymorphisms ( $\mathrm{T}+\mathrm{A}$ group) was correlated with increased arousal levels $(P=0.004, \quad r=0.26$, medium effect), increased orgasm levels $(P=0.033, r=0.18$, small effect) and increased FSFI_full levels $(P=0.026, r=0.19$, small effect). There was a statistical trend for increased desire levels in the $\mathrm{T}+\mathrm{A}$ group $(P=0.075)$ (Table 3$)$.

The presence of $\mathrm{T}$ allele of rs2234693 (PvuII) polymorphism concurrently with the absence of $\mathrm{A}$ allele of rs53576 (OXTR) polymorphism was correlated with increased satisfaction levels $(P=0.039, r=0.26$, medium effect), increased FAI levels and decreased SHBG levels compared to carriers of A allele of rs53576 (OXTR) polymorphism concomitantly with the absence of T allele of rs2234693 (PvuII) polymorphism (Table 3).

Table 3 Comparison of hormonal characteristics and sexual parameters between women who carry both T allele of rs223493 (Pvull) and A allele of rs53576 (OXTR) $(T+A$ group) and the no $(T+A)$ group and between women who carry $T$ allele and no $A$ allele ( $T+$ no $A$ group) and those who carry $A$ allele and no $T$ allele (no $T+A$ group) (bold indicates significance level: $P<0.05)$.

\begin{tabular}{|c|c|}
\hline & $\mathbf{T}+\mathbf{A}(N=53)$ \\
\hline Age & $21.49(1.89)$ \\
\hline $\mathrm{FSH}(\mathrm{IU} / \mathrm{mL})$ & $6.37(1.60)$ \\
\hline LH (IU/mL) & $5.95(2.42)$ \\
\hline $\mathrm{E} 2(\mathrm{pg} / \mathrm{mL})$ & $43.12(13.20)$ \\
\hline Progesterone (ng/mL) & $9.66(6.98)$ \\
\hline Testosterone (ng/dL) & $0.30(0.09)$ \\
\hline SHBG (nmol/L) & $67.45(29.85)$ \\
\hline FAI & $2.05(1.47)$ \\
\hline Desire & $4.44(0.88)$ \\
\hline Arousal & $5.28(1.02)$ \\
\hline Lubrication & $5.43(0.97)$ \\
\hline Orgasm & $5.01(1.31)$ \\
\hline Satisfaction & $5.25(1.08)$ \\
\hline Pain & $4.98(1.55)$ \\
\hline FSFI_full & $30.43(5.24)$ \\
\hline Menarche & $12.22(1.17)$ \\
\hline Adrenarche & $10.18(1.14)$ \\
\hline Age of first intercourse & $17.67(2.00)$ \\
\hline Number of sex partners & $3.79(3.34)$ \\
\hline
\end{tabular}
http://www.endocrineconnections.org
DOI: 10.1530/EC-16-0090

\begin{tabular}{c}
\hline No $(\mathbf{T}+\mathbf{A})(N=80)$ \\
\hline $21.71(1.95)$ \\
$6.63(1.50)$ \\
$5.93(2.06)$ \\
$43.99(16.46)$ \\
$9.83(7.69)$ \\
$0.31(0.08)$ \\
$70.92(29.84)$ \\
$1.94(1.36)$ \\
$4.11(0.97)$ \\
$4.86(1.26)$ \\
$5.18(1.27)$ \\
$4.62(1.44)$ \\
$5.19(1.11)$ \\
$4.90(1.54)$ \\
$28.88(6.14)$ \\
$12.44(1.34)$ \\
$10.42(1.49)$ \\
$17.93(1.83)$ \\
$3.38(3.95)$ \\
\end{tabular}

\begin{tabular}{l}
\hline P value \\
\hline 0.469 \\
0.351 \\
0.515 \\
0.748 \\
0.856 \\
0.691 \\
0.499 \\
0.748 \\
$\mathbf{0 . 0 7 5}$ \\
$\mathbf{0 . 0 0 4}$ \\
0.181 \\
$\mathbf{0 . 0 3 3}$ \\
0.713 \\
0.624 \\
$\mathbf{0 . 0 2 6}$ \\
0.485 \\
0.637 \\
0.242 \\
0.428 \\
\hline
\end{tabular}

\begin{tabular}{c}
\hline T+no A $(N=49)$ \\
\hline $21.61(2.09)$ \\
$6.67(1.62)$ \\
$5.90(2.14)$ \\
$43.88(15.81)$ \\
$9.86(7.81)$ \\
$0.32(0.07)$ \\
$69.44(33.01)$ \\
$2.10(1.56)$ \\
$4.12(0.91)$ \\
$5.02(1.18)$ \\
$5.27(1.29)$ \\
$4.66(1.41)$ \\
$5.33(1.13)$ \\
$4.95(1.56)$ \\
$29.38(6.08)$ \\
$12.43(1.38)$ \\
$10.53(1.45)$ \\
$18.08(1.89)$ \\
$3.67(4.69)$ \\
\end{tabular}

\begin{tabular}{c}
\hline No T+A $(N=16)$ \\
\hline $21.81(1.37)$ \\
$6.57(1.20)$ \\
$6.02(1.80)$ \\
$42.07(16.59)$ \\
$9.65(7.50)$ \\
$0.28(0.09)$ \\
$82.33(27.61)$ \\
$1.40(0.86)$ \\
$4.12(1.02)$ \\
$4.51(1.69)$ \\
$4.80(1.55)$ \\
$4.45(1.61)$ \\
$4.92(0.96)$ \\
$4.32(1.92)$ \\
$27.14(7.59)$ \\
$12.37(0.95)$ \\
$9.87(1.31)$ \\
$17.43(1.36)$ \\
$3.06(2.46)$ \\
\hline
\end{tabular}

\begin{tabular}{l}
\hline P value \\
\hline 0.264 \\
0.827 \\
0.594 \\
0.695 \\
0.897 \\
0.101 \\
$\mathbf{0 . 0 4 9}$ \\
$\mathbf{0 . 0 1 9}$ \\
0.92 \\
0.464 \\
$\mathbf{0 . 0 7}$ \\
0.689 \\
$\mathbf{0 . 0 3 9}$ \\
0.157 \\
0.229 \\
0.82 \\
0.16 \\
0.171 \\
0.857 \\
\end{tabular}




\section{Discussion}

In the present study, a genetic predisposition of female sexual response was revealed. More specifically, T allele (wildtype) of rs2234693 (PvuII) polymorphism of ERA gene was correlated with increased levels of arousal and lubrication, whereas A allele (polymorphic) of rs53576 (OXTR) polymorphism with increased arousal levels. The concurrence of T allele (wildtype) of ERA rs2234693 polymorphism and A allele (polymorphic) of OXTR rs53576 polymorphism was correlated with increased arousal and orgasm levels as well as with higher FSFI_full scores. To our knowledge, this is the first study that investigates the interaction between genetic polymorphisms of ERA and OXTR genes and sexuality parameters.

Our findings are a genetic confirmation of clinical data supporting the cardinal role estrogens play in female sexual activity. In healthy premenopausal women with normal sexual activity who underwent pharmacologically induced hypogonadism, a statistically significant reduction in sexuality parameters has been documented (35). Robust evidence on the prominent role of estrogens in sexual desire are increased levels of libido reported during follicular phase of menstrual cycle as well as in periovulatory period $(36,37)$. Furthermore, in cases of estrogen deficiency, aggravation of sexual parameters is thoroughly studied. In women with premature ovarian failure (POF), sexual function has been shown to be impaired, especially in the domains of desire and arousal (38). In menopausal period, sexual arousal response is impaired not only because of a decrease in genital vasocongestion and lubrication leading to atrophy of the vaginal epithelium but also because of mood changes from estrogen deprivation and its adverse effects on psychological perception of sexual arousal (39).

Concerning oxytocin, in our study, it was shown that A allele (polymorphic) of rs53576 (OXTR) polymorphism was correlated with increased arousal levels. It is well known that OXTR is implicated in female sexual response. Based on data from animal studies, female pelvic organs involved in (pre-) copulatory behavior are provided with OXTR and oxytocin neural fibers descending into the lumbosacral parts of the spinal cord $(40,41,42)$. Peripheral and central effects on the pelvic organs are implicated in the preparation for the copulatory activities with regard to lubrication, muscular contractility and pain suppression for the coming vagino-cervical distension $(43,44,45,46$, $47,48,49,50)$.

Studies on humans confirm the presence of OXTR on female genital organs indicating a possible 'preparatory role' of oxytocin for the later and final phases of the copulatory process, exerting a direct effect on sensory nerve sensitivity, 'preparing' thus muscular contractions and lubrication effects (51).

Given that there is no functional analysis concerning rs53576 polymorphism, the mechanism by which this polymorphism is implicated in sexual arousal could be elucidated based on data from behavioral traits. It is established that A allele of OXTR rs53576 has been associated with decreased hypothalamus and amygdala volumes, which are brain areas that are extensively involved in the regulation of social and emotional behaviors $(52,53)$. Empathy is defined as the capacity to experience feelings of compassion, warmth and concern in response to other people. Empathy is a complex socioemotional competency that encompasses components including empathic arousal and empathic concern (54). Individual levels of empathy may be associated with individual differences in unconscious sharing of affect experienced while viewing others in physical distress. Lower scores of empathic concern were associated with A allele of OXTR rs53576 polymorphism (55). It has been suggested that empathic tendencies magnify vulnerability for psychological disorders under certain conditions. Increased risk for personal distress and excessive interpersonal guilt in cases of enhanced propensities for empathic sensitivity have been suggested. Personal distress and interpersonal guilt, in turn, contribute to heightened risk for fear/arousal symptoms and anhedonia/misery symptoms, respectively (56). Consequently, it could be presumed that lower scores of empathy could be associated with increased levels of sexual arousal.

The concurrence of $\mathrm{T}$ allele (wildtype) of ERA rs2234693 polymorphism and A allele (polymorphic) of OXTR rs53576 polymorphism was correlated with increased arousal and orgasm levels as well as with higher FSFI_full scores, whereas there was a trend for increased desire levels. It seems that the favorable impact of these alleles on sexuality parameters is synergistic, given that the exclusive presence of $\mathrm{T}$ allele of ERA rs2234693 was correlated only with increased satisfaction levels compared to the exclusive presence of A allele of OXTR rs53576. Interaction between estrogens and oxytonergic system is well established. Estrogens have been shown to increase OXTR binding (27), whereas oxytocin has been found to increase expression of ERA (28).

The results of the present study do not seem to be in line with those found in the literature. Neither ERA-rs2234693 nor OXTR-rs53576 has been shown to account for variability of sexual response. One candidate 
gene study has linked serotonin polymorphisms (5HT2A) to reduced sexual desire as a side effect of SSRI medication in 89 adult men and women (57). A further study reported an association between the dopamine D4 receptor gene (DRD4) with self-reports of sexual desire and arousal in 52 men and 92 women (58). Interleukin1beta gene $(I L 1 B)$ has been correlated with variation in vulvar vestibulitis syndrome scores, a broader phenotype for sexual pain symptoms (59). On a genome-wide association study (GWAS) on 2.5 million single-nucleotide polymorphisms, three polymorphic sites (rs13202860, rs1876525 and rs13209281) around $500 \mathrm{~kb}$ upstream of the locus HTR1E (5-hydroxytryptamine receptor 1E) were associated with arousal (10). Although female sexuality has been associated with ERB gene polymorphisms, ERA gene polymorphisms have not been related to sexuality parameters $(9,10)$. Gunst and coworkers reported no association of rs2234693 polymorphism of ERA gene with any sexuality parameters (9). This could be attributed to the fact that ERA is involved in sexual behavior via multiple and complicated mechanisms that have not been fully elucidated yet, whereas the mechanisms of ERB action concerning female sexuality seem to be limited. Therefore, a polymorphism of ERB gene affecting receptor affinity could be directly related to sexual behavior, while the presence of a single ERA polymorphism may not have an impact on sexuality. In fact, estrogen effect on sexuality is the result of $E R A$ and $E R B$ interaction. Consequently, although single polymorphisms in ERA gene may be impotent in exerting an effect on sexual behavior, the importance of ERA in female sexuality is paramount compared to that of ERB, given that ERA knockout mice did not display sexual behavior, whereas ERB knockout mice exhibited lordosis behavior equal to wildtype ones (60). Our study is the first that finds a relationship between ERA gene polymorphism and sexuality parameters. Furthermore, this is the first study that highlights the favorable synergistic impact of wildtype allele of ERA gene rs2234693 ( $\mathrm{T}$ allele) and polymorphic allele of OXTR rs53576 (A allele) on sexuality parameters.

However, in drawing overall conclusions, we must take notice of limitations of the current study. The sample is not representative of the general population as it comes from higher education women, whereas sample size is rather small. Another limitation could be the short time span (4 weeks) of FSFI questionnaire. Given that female sexuality is a behavioral phenotype that is quite complex, women's short-term sexual functioning can fluctuate, rendering assessment of sexual functioning speculative.
Moreover, the data investigating the association between these polymorphisms and sexual function in women are sparse, whereas candidate gene association studies generate inconclusive results. Failure to replicate genotype studies is common in candidate gene association studies (61). In fact, no genetic study on female sexuality has been successfully replicated (9). Further research and replication of the results are needed to clarify such issues.

In conclusion, female sexuality is a complex behavior that encompasses both biological and psychological components. It seems that endocrine, neurotransmitter and CNS's influences affect parameters of female sexuality characterized by genetic variability due to the presence of a variety of individual genetic polymorphisms such as those concerning ERA and OXTR genes.

\section{Declaration of interest}

The authors declare that there is no conflict of interest that could be perceived as prejudicing the impartiality of the research reported.

\section{Funding}

This research did not receive any specific grant from any funding agency in the public, commercial or not-for-profit sector.

\section{References}

1 Witting K, Santtila P, Rijsdijk F, Varjonen M, Jern P, Johansson A, von der Pahlen B, Alanko K \& Sandnabba NK. Correlated genetics and non-shared environmental influences account for the co-morbidity between female sexual dysfunctions. Psychological Medicine $20083 \mathbf{8}$ 1-13. (doi:10.1017/s0033291708003206)

2 Burri A, Greven C, Leupin M, Spector T \& Rahman Q. A multivariate twin study of female sexual dysfunction. Journal of Sexual Medicine 201210 2671-2681. (doi:10.1111/j.1743-6109.2012.02861.x)

3 Bancroft J. The endocrinology of sexual arousal. Journal of Endocrinology 2005186 411-427. (doi:10.1677/joe.1.06233)

4 Goldstein JM, Jerram M, Poldrack R, Ahern T, Kennedy DN, Seidman LJ \& Makris N. Hormonal cycle modulates arousal circuitry in women using functional magnetic resonance imaging. Journal of Neuroscience 200525 9309-9316. (doi:10.1523/ JNEUROSCI.2239-05.2005)

5 Salonia A, Giraldi A, Chivers ML, Georgiadis JR, Levin R, Maravilla KR \& McCarthy MM. Physiology of women's sexual function: basic knowledge and new findings. Journal of Sexual Medicine 20107 2637-2660. (doi:10.1111/j.1743-6109.2010.01810.x)

6 Meston CM \& Frohlich PF. The neurobiology of sexual function. Archives of General Psychiatry 200057 1012-1013. (doi:10.1001/ archpsyc.57.11.1012)

7 Graziottin A. Libido: the biologic scenario. Maturitas 200034 (Supplement 1) S9-S16. (doi:10.1016/S0378-5122(99)00072-9)

8 Nappi R, Salonia A, Traish AM, van Lunsen RH, Vardi Y, Kodiglu A \& Goldstein I. Clinical biologic pathophysiologies of women's sexual dysfunction. Journal of Sexual Medicine 20052 4-25. (doi:10.1111/ j.1743-6109.2005.20102.x)

9 Gunst A, Jern P, Westberg L, Johansson A, Salo B, Burri A, Spector T, Eriksson E, Sandnabba NK \& Santtila P. A study of possible associations between single nucleotide polymorphisms in the

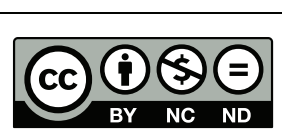

This work is licensed under a Creative Commons Attribution-NonCommercial-NoDerivatives 4.0 International License. 
estrogen receptor 2 gene and female sexual desire. Journal of Sexual Medicine 201512 676-684. (doi:10.1111/jsm.12753)

10 Burri A, Hysi P, Clop A, Rahman Q \& Spector TD. A genome-wide association study of female sexual dysfunction. PLOS ONE 20127 e35041. (doi:10.1371/journal.pone.0035041)

11 Maruyama H, Toji H, Harrington CR, Sasaki K, Izumi Y, Ohnuma T, Arai H, Yasuda M, Tanaka C, Emson PC, et al. Lack of an association of estrogen receptor alpha gene polymorphisms and transcriptional activity with Alzheimer disease. Archives of Neurology $2000 \mathbf{5 7}$ 236-240. (doi:10.1001/archneur.57.2.236)

12 Corbo RM, Ulizzi L, Piombo L, Martinez-Labarga C, De Stefano GF \& Scacchi R. Estrogen receptor alpha polymorphisms and fertility in populations with different reproductive patterns. Molecular Human Reproduction 200713 537-540. (doi:10.1093/molehr/gam041)

13 Kirsch P. Oxytocin in the socioemotional brain: implications for psychiatric disorders. Dialogues in Clinical Neuroscience 201517 463-476.

14 Miller TV \& Caldwell HK. Oxytocin during development: possible organizational effects on behavior. Frontiers in Endocrinology 2015 676

15 Kramer KM, Yoshida S, Papademetriou E \& Cushing BS. The organizational effects of oxytocin on the central expression of estrogen receptor alpha and oxytocin in adulthood. BMC Neuroscience 20078 71. (doi:10.1186/1471-2202-8-71)

16 Carmichael MS, Humbert R, Dixen J, Palmisano G, Greenleaf W \& Davidson JM. Plasma oxytocin increases in the human sexual response. Journal of Clinical Endocrinology and Metabolism 198764 27-31. (doi:10.1210/jcem-64-1-27)

17 Anderson-Hunt M \& Dennerstein L. Increased female sexual response after oxytocin. British Medical Journal 1994309 929. (doi:10.1136/ bmj.309.6959.929)

18 Anderson-Hunt M \& Dennerstein L. Oxytocin and female sexuality. Gynecologic and Obstetric Investigation 199540 217-221. (doi:10.1159/000292340)

19 Blaicher W, Gruber D, Bieglmayer C, Blaicher AM, Knogler W $\&$ Huber JC. The role of oxytocin in relation to female sexual arousal. Gynecologic and Obstetric Investigation 199947 125-126. (doi:10.1159/000010075)

20 Gimpl G \& Fahrenholz F. The oxytocin receptor system: structure, function, and regulation. Physiological Reviews 200181 629-683.

21 Li J, Zhao Y, Li R, Broster LS, Zhou C \& Yang S. Association of oxytocin receptor gene (OXTR) rs53576 polymorphism with sociality: a meta-analysis. PLoS ONE 201510 e0131820. (doi:10.1371/journal. pone.0131820)

22 Normandin JJ \& Murphy AZ. Somatic genital reflexes in rats with a nod to humans: anatomy, physiology, and the role of the social neuropeptides. Hormones and Behavior 201159 656-665. (doi:10.1016/j.yhbeh.2011.02.006)

23 Kudwa AE \& Rissman EF. Double oestrogen receptor alpha and beta knockout mice reveal differences in neural oestrogen-mediated progestin receptor induction and female sexual behaviour. Journal of Neuroendocrinology 200315 978-983. (doi:10.1046/j.13652826.2003.01089.x)

24 Bakker J, Honda S, Harada N \& Balthazart J. The aromatase knockout mouse provides new evidence that estradiol is required during development in the female for the expression of sociosexual behaviors in adulthood. Journal of Neuroscience 200222 9104-9112.

25 Sowers MR, Jannausch ML, McConnell DS, Kardia SR \& Randolph JF Jr. Endogenous estradiol and its association with estrogen receptor gene polymorphisms. American Journal of Medicine 2006119 (Supplement 1) S16-S22. (doi:10.1016/j.amjmed.2006.07.002)

26 Feldman R, Monakhov M, Pratt M \& Ebstein RP. Oxytocin pathway genes: evolutionary ancient system impacting on human affiliation, sociality, and psychopathology. Biological Psychiatry 201679 174-184. (doi:10.1016/j.biopsych.2015.08.008)
27 McCarthy MM, Kleopoulos SP, Mobbs CV \& Pfaff DW. Infusion of antisense oligodeoxynucleotides to the oxytocin receptor in the ventromedial hypothalamus reduces estrogen-induced sexual receptivity and oxytocin receptor-binding in the female rat. Neuroendocrinology 199459 432-440. (doi:10.1159/000126689)

28 Pournajafi-Nazarloo H, Carr MS, Papademeteriou E, Schmidt JV \& Cushing BS. Oxytocin selectively increases ER $\alpha$-mRNA in the neonatal hypothalamus and hippocampus of female prairie voles. Neuropeptides 200741 39-44. (doi:10.1016/j.npep.2006.10.002)

29 Rosen R, Brown C, Heiman J, Leiblum S, Meston C, Shabsigh R, Ferguson D \& D'Agostino R Jr. The Female Sexual Function Index (FSFI): a multidimensional self-report instrument for the assessment of female sexual function. Journal of Sex and Marital Therapy 200026 191-208. (doi:10.1080/009262300278597)

30 Matzaroglou C, Assimakopoulos K, Panagiotopoulos E, Kasimatis G, Dimakopoulos P \& Lambiris E. Sexual function in females with severe cervical spinal cord injuries: a controlled study with the female sexual function index. International Journal of Rehabilitation Research 200528 375-377. (doi:10.1097/00004356-200512000-00014)

31 Assimakopoulos K, Panayiotopoulos S, Iconomou G, Karaivazoglou K, Matzaroglou C, Vagenas K \& Kalfarentzos F. Assessing sexual function in obese women preparing for bariatric surgery. Obesity Surgery 2006 16 1087-1091. (doi:10.1381/096089206778026442)

32 Assimakopoulos K, Karaivazoglou K, Panayiotopoulos S, Hyphantis T, Iconomou G \& Kalfarentzos F. Bariatric surgery is associated with reduced depressive symptoms and better sexual function in obese female patients: a one-year follow-up study. Obesity Surgery 201121 362-336. (doi:10.1007/s11695-010-0303-z)

33 White ID, Sangha A, Lucas G \& Wiseman T. Assessment of sexual difficulties associated with multi-modal treatment for cervical or endometrial cancer: a systematic review of measurement instruments. Gynecologic Oncology 2016143 664-673. (doi:10.1016/j. ygyno.2016.08.332)

34 Jorgensen TJ, Ruczinski I, Kessing B, Smith MW, Shugart YY \& Alberg AJ. Hypothesis-driven candidate gene association studies: practical design and analytical considerations. American Journal of Epidemiology 2009170 986-993. (doi:10.1093/aje/kwp242)

35 Ben Dor R, Harsh VL, Fortinsky P, Koziol DE, Rubinow DR \& Schmidt PJ. Effects of pharmacologically induced hypogonadism on mood and behavior in healthy young women. American Journal of Psychiatry 2013170 426-433. (doi:10.1176/appi.ajp.2012.12010117)

36 Dennerstein L, Gotts G, Brown JB, Morse CA, Farley TM \& Pinol A. The relationship between the menstrual cycle and female sexual interest in women with PMS complaints and volunteers. Psychoneuroendocrinology 199419 293-304. (doi:10.1016/03064530(94)90067-1)

37 Wilcox AJ, Day Baird D, Dunson DB, McConnaughey DR, Kesner JS $\&$ Weinberg CR. On the frequency of intercourse around ovulation: evidence for biological influences. Human Reproduction 200419 1539-1543. (doi:10.1093/humrep/deh305)

38 Benetti-Pinto CL, Soares PM, Giraldo HP \& Yela DA. Role of the different sexuality domains on the sexual function of women with premature ovarian failure. Journal of Sexual Medicine 201512 685-689. (doi:10.1111/jsm.12743)

39 Meston CM \& Frohlich PF. The neurobiology of sexual function. Archives of General Psychiatry 200057 1012-1030. (doi:10.1001/ archpsyc.57.11.1012)

40 Buijs RM. Intra- and extrahypothalamic vasopressin and oxytocin pathways in the rat. Pathways to the limbic system, medulla oblongata and spinal cord. Cell and Tissue Research 1978192 423-435. (doi:10.1007/BF00224932)

41 Normandin JJ \& Murphy AZ. Somatic genital reflexes in rats with a nod to humans: anatomy, physiology, and the role of the social neuropeptides. Hormones and Behavior 201159 656-665. (doi:10.1016/j.yhbeh.2011.02.006) 
42 Swanson LW \& McKellar S. The distribution of oxytocin and neurophysin-stained fibers in the spinal cord of the rat and monkey. Journal of Comparative Neurology 1979188 87-106. (doi:10.1002/ cne.901880108)

43 Devost D, Wrzal P \& Zingg HH. Oxytocin receptor signalling. Progress in Brain Research 2008170 167-176. (doi:10.1016/s00796123(08)00415-9)

44 Gelez H, Poirier S, Facchinetti P, Allers KA, Wayman C, Alexandre L \& Giuliano F. Neuroanatomical evidence for a role of central melanocortin-4 receptors and oxytocin in the efferent control of the rodent clitoris and vagina. Journal of Sexual Medicine 20107 2056-2067. (doi:10.1111/j.1743-6109.2010.01760.x)

45 Giraldi A, Marson L, Nappi R, Pfaus J, Traish AM, Vardi Y \& Goldstein I. Physiology of female sexual function:animal models. Journal of Sexual Medicine 20041 237-253. (doi:10.1111/j.1743-6109.04037.x)

46 Magon N \& Kalra S. The orgasmic history of oxytocin: love, lust, and labor. Indian Journal of Endocrinology and Metabolism $2011 \mathbf{1 5}$ (Supplement 3) S156-S161. (doi:10.4103/2230-8210.84851)

47 Moos F \& Richard P. Level of oxytocin release induced by vaginal dilatation (Ferguson reflex) and vagal stimulation (vago-pituitaryreflex) in lactating rats. Journal of Physiology $1975 \mathbf{7 0}$ 307-314.

48 Peters LC, Kristal MB \& Komisaruk BR. Sensory innervation of the external and internal genitalia of the female rat. Brain Research 1987 408 199-204. (doi:10.1016/0006-8993(87)90372-6)

49 Sansone GR \& Komisaruk BR. Evidence that oxytocin is an endogenous stimulator of autonomic sympathetic preganglionics: the pupillary dilatation response to vaginocervical stimulation in the rat. Brain Research 2001898 265-271. (doi:10.1016/S00068993(01)02192-8)

50 Wilson LA, Wayman CP \& Jackson VM. Neuropeptide modulation of a lumbar spinal reflex: potential implications for female sexual function. Journal of Sexual Medicine 20096 947-957. (doi:10.1111/ j.1743-6109.2008.01150.x)

51 Gimpl G \& Fahrenhol F. The oxytocin receptor system: structure, function, and regulation. Physiological Reviews 200181 629-683.

52 Ebstein RP, Knafo A, Mankuta D, Chew SH \& Lai PS. The contributions of oxytocin and vasopressin pathway genes to human behavior. Hormones and Behavior 201261 359-379. (doi:10.1016/j. yhbeh.2011.12.014
53 Tost H, Kolachana B, Hakimi S, Lemaitre H, Verchinski BA, Mattay VS, Weinberger DR \& Meyer-Lindenberg A. A common allele in the oxytocin receptor gene (OXTR) impacts prosocial temperament and human hypothalamic-limbic structure and function. PNAS 2010107 13936-13941. (doi:10.1073/pnas.1003296107)

54 Decety J, Norman GJ, Berntson GG \& Cacioppo JT. A neurobehavioral evolutionary perspective on the mechanisms underlying empathy. Progress in Neurobiology 201298 38-48. (doi:10.1016/j. pneurobio.2012.05.001)

55 Smith KE, Porges EC, Norman GJ, Connelly JJ \& Decety J. Oxytocin receptor gene variation predicts empathic concern and autonomic arousal while perceiving harm to others. Society for Neuroscience 2014 9 1-9. (doi:10.1080/17470919.2013.863223)

56 Tone EB \& Tully EC. Empathy as a 'risky strength': a multilevel examination of empathy and risk for internalizing disorders. Development and Psychopathology 201426 1547-1565. (doi:10.1017/ S0954579414001199)

57 Bishop JR, Moline J, Ellingrod VL, Schultz SK \& Clayton AH. Serotonin 2A-1438 G/A and G-protein Beta3 subunit C825T polymorphismms in patients with depression and SSRI-associated sexual side-effects. Neuropsychopharmacology 200631 2281-2288. (doi:10.1038/sj.npp.1301090)

58 Ben Zion IZ, Tessler R, Cohen L, Lerer E, Raz Y, Bachner-Melman R, Gritsenko I, Nemanov L, Zohar AH, Belmaker RH, et al. Polymorphisms in the dopamine D4 receptor gene (DRD4) contribute to individual differences in human sexual behavior: desire, arousal and sexual function. Molecular Psychiatry 200611 782-786. (doi:10.1038/sj.mp.4001832)

59 Gerber S, Bongiovanni AM, Ledger WJ \& Witkin SS. Interleukin1beta gene polymorphism in women with vulvar vestibulitis syndrome. European Journal of Obstetrics and Gynecology and Reproductive Biology 2003107 74-77. (doi:10.1016/S03012115(02)00276-2)

60 Kudwa AE, Michopoulos V, Gatewood JD \& Rissman EF. Roles of estrogen receptors alpha and beta in differentiation of mouse sexual behavior. Neuroscience 2006138 921-928. (doi:10.1016/j. neuroscience.2005.10.018)

61 Burmeister M, McInnis MG \& Zöllner S. Psychiatric genetics: progress amid controversy. Nature Reviews Genetics 20089 527-540. (doi:10.1038/nrg2381)

Received in final form 19 December 2016

Accepted 9 January 2017

Accepted Preprint published online 9 January 2017 http://www.endocrineconnections.org DOI: 10.1530/EC-16-0090
(C) 2017 The authors Published by Bioscientifica Ltd
This work is licensed under a Creative Commons Attribution-NonCommercial-NoDerivatives 4.0 International License. 